\title{
METASTABLE PHASES AND MACROHETEROGENEOUS COMPOSITES
}

\author{
O.V. Sukhova \\ Oles' Honchar Dnipro National University, Dnipro, Ukraine \\ e-mail: sukhovaya@ukr.net
}

The way to control the interfacial reactions that processes during infiltration of macroheterogeneous composite materials is suggested. The idea is to combine the stable and metastable phases in the filler's structure which dissolves at a different rate in the molten binder. To prove this approach, the structure and gas-abrasive wear of macroheterogeneous composite materials with $\mathrm{Cu}-20 \mathrm{Ni}-20 \mathrm{Mn}$ binder reinforced by Fe-(9.0-10.0)B-(0.01-0.2)C filler (in wt. \%) cooled at $10-20 \mathrm{~K} / \mathrm{s}$ or $10^{3}-10^{4} \mathrm{~K} / \mathrm{s}$ are studied. It is shown that the wear resistance of the investigated composite materials can be enhanced by accelerating interfacial reactions between the filler and the molten binder. Therefore, the composite materials produced from a rapidly cooled $\mathrm{Fe}-\mathrm{B}-\mathrm{C}$ filler show a higher resistance to gas-abrasive wear due to formation of $\mathrm{Fe}-\mathrm{Fe}_{2}(\mathrm{~B}, \mathrm{C})$ metastable eutectics in its structure. This eutectics crystallizes under metastable phase diagram due to the suppression of stable $\mathrm{Fe}_{2}(\mathrm{~B}, \mathrm{C})$ phase formation and saturation of the rest of liquid by iron in the filler cooled at $10^{3}-10^{4} \mathrm{~K} / \mathrm{s}$. As a result of rapid dissolution of the eutectics in the molten binder during infiltration, the strong adhesion at the interfaces of the composite materials is achieved which prevents the filler from spalling out under the impacts of abrasive.

Keywords: composite material, infiltration, filler, stable and metastable phases, resistance to gas-abrasive wear.

Received 02.06.2021; Received in revised form 20.07.2021; Accepted 15.08.2021

\section{Introduction}

In the last years, composite materials have been a matter of active investigation and development [1]. These materials show attractive properties, such as hardness, wear, oxidation, and corrosion resistance due to unique combination of ductile properties of metal matrix and tough properties of reinforcing particles.

Liquid metal infiltration without applying pressure (called furnace infiltration) is a usual route to produce metal matrix composites [2,3]. Thus, furnace infiltration provides good quality of macroheterogeneous composites given that molten metal binder is wetting filler material not forming brittle phases at the interfaces. Technology of furnace infiltration allows fabricating one-layer or multilayer composite coatings for various applications [4]. Layers of the composites may differ in the filler or the matrix compositions. They can be utilized for excellent abrasive or corrosive resistance. Therefore, despite the good results obtained with this technique, some difficulties remain related with control of interfacial reactions between the molten binder and the reinforcing particles.

To overcome these problems, special attention should be devoted to filler's phase composition since combining stable and metastable phases in its structure is an effective way to control dissolution and diffusion processes between the molten matrix and the filler during infiltration [5]. The fact is that metastable phases are more reactive as compared with stable phases. Therefore, they usually dissolve in the molten metals at higher rate than stable ones. So, if necessary, interfacial reactions may be accelerated by increasing content of metastable phases in the filler's structure or vice versa.

Considering this approach, interfacial reactions in macroheterogeneous composites reinforced with $\mathrm{Fe}-\mathrm{B}-\mathrm{C}$ filler and resistance of these composites to gas-abrasive wear were investigated as a function of metastable phases content in the filler's structure.

\section{Experimental procedure}

Macroheterogeneous composites were fabricated by infiltration at a temperature of 1323 $\mathrm{K}$ for $45 \mathrm{~min}$. $\mathrm{Cu}-20 \mathrm{Ni}-20 \mathrm{Mn}$ alloy was used as binder. The fillers were prepared from $\mathrm{Fe}-\mathrm{B}-\mathrm{C}$ alloys of compositions $9.0-10.0 \mathrm{~B}, 0.01-0.2 \mathrm{C}$, the rest being $\mathrm{Fe}$ (in wt. \%), by mechanical crushing $\left(\mathrm{v}_{\mathrm{cool}}=10-20 \mathrm{~K} / \mathrm{s}\right)$ or thermocentrifugal atomization of a rotating bar 
$\left(\mathrm{v}_{\text {cool }}=10^{3}-10^{4} \mathrm{~K} / \mathrm{s}\right)$ [5]. In the first case the filler particles were of irregular shape, in the second case they were spherical. The particle sizes varied from 0.2 to $2.5 \mathrm{~mm}$. After preparation, the major constituents of the $\mathrm{Fe}-\mathrm{B}-\mathrm{C}$ fillers were found to be crystals of $\mathrm{Fe}(\mathrm{B}, \mathrm{C})$ and $\mathrm{Fe}_{2}(\mathrm{~B}, \mathrm{C})[6]$.

The structure of the composites was studied by quantitative metallographic and Xray analyses using standard procedures. The resistance of composites to gas-abrasive wear was determined on a device in which specimens were fixed with certain angles. Quartz sand particles impacted specimens at an angle of $45^{\circ}$. For each period, the measured erodent quantity was $6 \mathrm{~kg}$. Not less than four tests of 35 mins each were run in ambient air (50-60\% humidity, room temperature or $673 \mathrm{~K})$. The specimens were tested against the composite material composed of the $\left(\mathrm{WC}+\mathrm{W}_{2} \mathrm{C}\right)$ carbides and $\mathrm{Cu}-20 \mathrm{Ni}-20 \mathrm{Mn}$ binder.

\section{Results and discussion}

The structure of composite materials depends on a cooling rate of the $\mathrm{Fe}-\mathrm{B}-\mathrm{C}$ filler during preparation. This of composites reinforced with the filler cooled at $10-20 \mathrm{~K} / \mathrm{s}$ is characterized by presence of angular shaped particles in a copper-based matrix (Fig. 1, a). The filler content of the infiltrated composites is 50-70 vol \%. The interfacial zones between the filler and the matrix are produced due to dissolution and diffusion processes. Around each particle forms a shell alloyed with Mn and, slightly, Ni, which differs in a higher iron content vs. that of the slowly cooled $\mathrm{Fe}-\mathrm{B}-\mathrm{C}$ filler after preparation $[7,8]$. Traces of $\mathrm{Fe}$ and $\mathrm{B}$ from the reinforcing particles are also revealed in the adjacent matrix. Brittle phases are not observed at the interfaces. At that, the interface width increases at the expense of the layer that dissolves and re-solidifies during the infiltration.

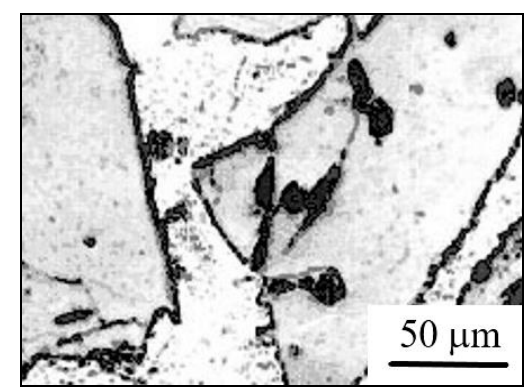

a



Fig. 1. Microstructure of composites reinforced with $\mathrm{Fe}-\mathrm{B}-\mathrm{C}$ fillers cooled during preparation at: $\mathrm{a}-10-20 \mathrm{~K} / \mathrm{s} ; \mathrm{b}-10^{3}-10^{4} \mathrm{~K} / \mathrm{s}$

After gas-abrasive tests of the composites, slowly cooled $\mathrm{Fe}-\mathrm{B}-\mathrm{C}$ particles which stand in relief to the surface are observed. Numerous scratches and cracks are revealed in the matrix, and only a few on the filler surface. The $\mathrm{Fe}-\mathrm{B}-\mathrm{C}$ alloys are hard and tough materials. Quartz cannot effectively erode $\mathrm{Fe}_{2}(\mathrm{~B}, \mathrm{C})$ and $\mathrm{Fe}(\mathrm{B}, \mathrm{C})$ phases of the filler. But it impinges copper-based matrix making numerous scratches. In addition, matrix wear is accelerated by the plastic deformation. Due to it, appear shallow cracks that can join, which leads to the separation of wear products. Gradual matrix wear around the $\mathrm{Fe}-\mathrm{B}-\mathrm{C}$ particles results in the emergence of the relief. Failure is also stipulated by spalling out of the reinforcing particles. Therefore, strengthening of adhesion between the filler and the matrix is of a great importance in this case which requires the increase in a dissolution rate of the filler's phases in the molten binder.

To accelerate interfacial reactions, low-melting phases should appear in the structure of the $\mathrm{Fe}-\mathrm{B}-\mathrm{C}$ filler. This result may be achieved with rapidly cooled alloys. 66 
Thus, as the cooling rate in producing the filler increases up to $10^{3}-10^{4} \mathrm{~K} / \mathrm{s}$, the filler acquires a microcrystalline structure [9]. Depending on the particles diameter, the size of $\mathrm{Fe}_{2}(\mathrm{~B}, \mathrm{C})$ crystals ranges from 1.0 to $4.5 \mu \mathrm{m}$. In addition, $\mathrm{Fe}-\mathrm{Fe}_{2}(\mathrm{~B}, \mathrm{C})$ metastable eutectics appears along the $\mathrm{Fe}_{2}(\mathrm{~B}, \mathrm{C})$ boundaries (Fig. 2, a, b). The metastable eutectics crystallizes because rapid cooling may suppress the formation of equilibrium $\mathrm{Fe}_{2}(\mathrm{~B}, \mathrm{C})$ phase [10]. As a result, the rest of the liquid is saturated by iron and its decomposition via eutectic reaction $\mathrm{L} \rightarrow \mathrm{Fe}+\mathrm{Fe}_{2}(\mathrm{~B}, \mathrm{C})$ becomes possible, as illustrated in Fig. 2, c. The metastable eutectics is produced by cooling at $10^{3}-10^{4} \mathrm{~K} / \mathrm{s}$ because there is no time for the atoms to be arranged in an equilibrium configuration.

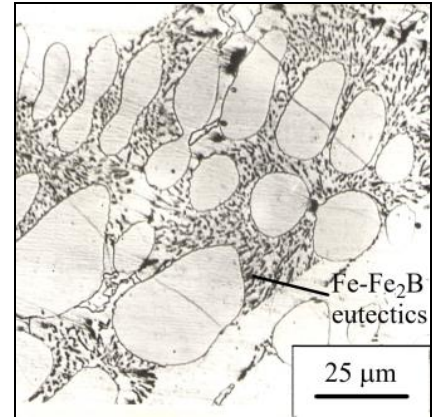

a

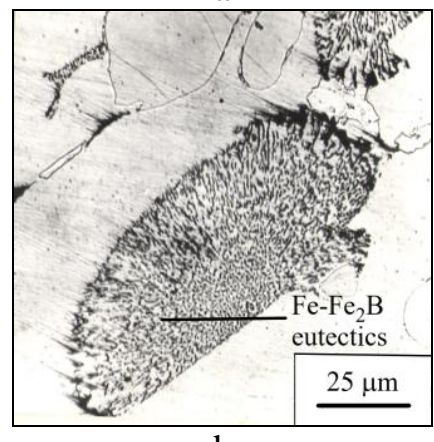

b

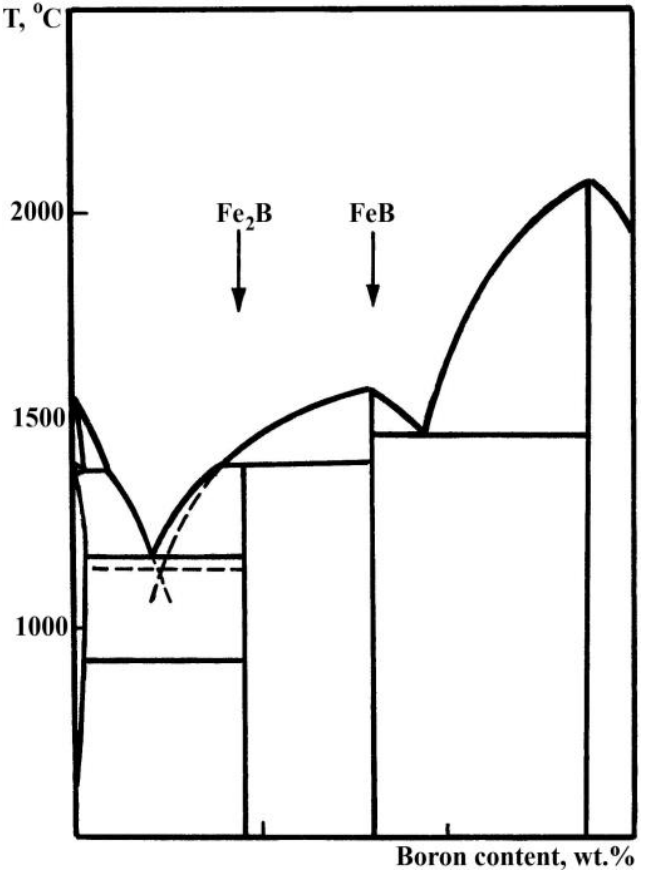

Fig. 2. Microstructure of rapidly cooled $\mathrm{Fe}-9 \mathrm{~B}-0.2 \mathrm{C}$ filler and $\mathrm{Fe}-\mathrm{B}$ phase diagram: $\mathrm{a}, \mathrm{b}-$ metallographic images; $\mathrm{c}-\mathrm{Fe}-\mathrm{B}$ phase diagram illustrating formation of metastable $\mathrm{Fe}-\mathrm{Fe}_{2} \mathrm{~B}$ eutectics

The composite materials reinforced with rapidly cooled $\mathrm{Fe}-\mathrm{B}-\mathrm{C}$ particles have the structure featuring so-called "through" infiltration by the metal binder [8]. It means that the contact interaction between the binder and the filler takes place not only at the interfaces of the composites, but inside the reinforcing particles at their $\mathrm{Fe}_{2}(\mathrm{~B}, \mathrm{C})$ boundaries. So, during the infiltration, non-uniform dissolution of the filler particles in the molten binder is observed. The binder mainly penetrates into the microcrystalline filler along the grain boundaries where the low-melting $\mathrm{Fe}-\mathrm{Fe}_{2}(\mathrm{~B}, \mathrm{C})$ metastable eutectics crystallizes during the atomization. Despite the deceleration of the dissolution of $\mathrm{Fe}(\mathrm{B}, \mathrm{C})$ and $\mathrm{Fe}_{2}(\mathrm{~B}, \mathrm{C})$ microcrystalline phases in the molten binder by a factor of 5-7 as compared with crystalline phases [9], the strong adhesion of the filler with a matrix is attained due to dissolution of metastable $\mathrm{Fe}-\mathrm{Fe}_{2}(\mathrm{~B}, \mathrm{C})$ eutectics.

As a result, the gas-abrasive wear resistance of the composites reinforced with rapidly cooled $\mathrm{Fe}-\mathrm{B}-\mathrm{C}$ filler increases (Table 1). No relief is seen on the surface of the composites. Scratches and cracks are observed along the entire worn surface. There are no traces of chipping or spalling out the filler under the impacts of abrasive that are observed on the worn surface of composites reinforced with slowly cooled $\mathrm{Fe}-\mathrm{B}-\mathrm{C}$ filler. 
Results of gas-abrasive tests of the composites reinforced with $\mathrm{Fe}-\mathrm{B}-\mathrm{C}$ fillers

\begin{tabular}{|c|c|c|}
\hline \multirow{2}{*}{ Cooling rate of filler, K/s } & \multicolumn{2}{|c|}{ Relative coefficient of gas-abrasive wear resistance, units } \\
\cline { 2 - 3 } & $293 \mathrm{~K}$ & $673 \mathrm{~K}$ \\
\hline $10-20$ & $0.74 \pm 0.17$ & $0.83 \pm 0.22$ \\
\hline $10^{3}-10^{4}$ & $0.91 \pm 0.08$ & $1.12 \pm 0.11$ \\
\hline
\end{tabular}

The strong adhesion of the rapidly cooled $\mathrm{Fe}-\mathrm{B}-\mathrm{C}$ filler with the $\mathrm{Cu}-20 \mathrm{Ni}-20 \mathrm{Mn}$ binder is assured due to higher rates of dissolution of metastable phases during the infiltration. Therefore, no spalling out of the $\mathrm{Fe}-\mathrm{B}-\mathrm{C}$ filler is revealed. After the binder solidification, the contact interaction zones form at the interfaces, which contain no brittle phases. Moreover, the hardness of the matrix due to alloying with iron and boron from the particles increases, and it resists to gas-abrasive wear more effectively. Therefore, failure in this case is caused only by cutting and scratching of the surface by abrasive.

\section{Conclusions}

Thus, by varying a content of phases in the $\mathrm{Fe}-\mathrm{B}-\mathrm{C}$ filler's structure which differ in stability under effect of molten metal binder, the interfacial reactions may be controlled during infiltration of macroheterogeneous composites. The resistance to gas-abrasive wear may be ensured by the presence of metastable phases in the filler's structure provided that an increase of their dissolution rate in the molten binder does not give rise to brittle phases formation at the interfaces.

\section{References}

1. Beaumont, P. Comprehensive composite materials / P. Beaumont, C. Zweben. 2rd edition. - London: Elsevier, 2018. - 635 p.

2. Spiridonova, I.M. Stabilnost kompozitsionnykh materialov / I.M. Spiridonova, A.D. Panasyuk, E.V. Sukhovaya, A.P. Umansky. - Dnipropetrovsk: Svidler, 2011. - 244 p.

3. Spiridonova, I.M. The use of composite coatings during metallurgical equipment parts repair / I.M. Spiridonova, E.V. Sukhovaya, S.B. Pilyaeva, O.G. Bezrukavaya // Metallurgicheskaya i Gornorudnaya Promyshlennost'. -2002. - No. 3. - P. 58-61.

4. Sukhova, O.V. Two-layered facing composites based on $\mathrm{Cr}-\mathrm{Ti}-\mathrm{C}$ filler / O.V. Sukhova // The Paton Welding J. - 2015. - No. 5-6. - P. 123-128.

5. Sukhovaya, E.V. Structural approach to the development of wear-resistant composite materials / E.V. Sukhovaya // J. Superhard Mater. - 2013. - Vol. 35, No. 5. - P. $277-283$.

6. Sukhova, O.V. The effect of carbon content and cooling rate on the structure of boron-rich $\mathrm{Fe}-\mathrm{B}-\mathrm{C}$ alloys / O.V. Sukhova // Physics and Chemistry of Solid State. 2020. - Vol. 21, No. 2. - P. 355-360.

7. Sukhova, O.V. Influence of mechanisms of structure formation of interfaces in composites on their properties / O.V. Sukhova // Metallofiz. Noveishie Technol. - 2009. - Vol. 31, No. 7. - P. 1001-1012.

8. Spiridonova, I.M. Multicomponent diffusion processes in boride-containing composite materials / I.M. Spiridonova, O.V. Sukhova, O.P. Vashchenko // Metallofiz. Noveishie Technol. - 1999. - Vol. 21, No. 2. - P. 122-125.

9. Sukhova, O.V. Physical and chemical processes at the interfaces of the composites reinforced with microcrystal filler / O.V. Sukhova, I.M. Spyrydonova // Conference Proceedings of the Intern. Conf. on Physical and Chemical Principles of Formation and Modification of Micro- and Nanostructures. - Kharkiv, 2008. - Vol. 2. - P. 327-330.

10. Miroshnichenko, I.S. Zakalka iz zhidkogo sostoyaniya / I.S. Miroshnichenko. Moscow: Metallurgiya, 1982. -168 p. 